\begin{tabular}{|l|l|l||}
\hline \multicolumn{2}{|c|}{ PublisherInfo } \\
\hline \hline PublisherName & $:$ & BioMed Central \\
\hline \hline PublisherLocation & $:$ & London \\
\hline \hline PublisherImprintName & $:$ & BioMed Central \\
\hline \hline
\end{tabular}

\title{
Reeling in DNA
}

\begin{tabular}{|l|l|l||}
\hline \multicolumn{2}{|c|}{ ArticleInfo } \\
\hline \hline ArticleID & $:$ & 3822 \\
\hline \hline ArticleDOI & $:$ & $10.1186 /$ gb-spotlight-20001108-01 \\
\hline \hline ArticleCitationID & $:$ & spotlight-20001108-01 \\
\hline \hline ArticleSequenceNumber & $:$ & 259 \\
\hline \hline ArticleCategory & $:$ & Research news \\
\hline \hline ArticleFirstPage & $:$ & 1 \\
\hline \hline ArticleLastPage & $:$ & 2 \\
\hline \hline & & RegistrationDate : 2000-11-08 \\
ArticleHistory & $:$ & OnlineDate $\quad: \quad 2000-11-08$ \\
\hline \hline ArticleCopyright & $:$ & BioMed Central Ltd2000 \\
\hline \hline ArticleGrants & $:$ & \\
\hline \hline ArticleContext & $:$ & 130591111 \\
\hline \hline
\end{tabular}




\section{William Wells}

Email: wells@biotext.com

The Bacillus subtilis SpoIIIE protein is required for DNA segregation during the asymmetric cell division that produces a mother cell and a pre-spore. In the 3 November Science, Bath et al. confirm that SpoIIIE is targeted to the leading edge of the septum that divides the two cells, and suggest that the protein pumps DNA into the pre-spore by tracking along DNA (Science 2000, 290:995-997). They find that SpoIIIE is a DNA-dependent ATPase that can introduce unconstrained supercoils into a DNA substrate. A DNA-packaging protein would tend to introduce constrained supercoils, but SpoIIIE presumably introduces positive supercoils in front of itself, as it tracks along the DNA, while the negative supercoils left in its wake are selectively relaxed by bacterial topoisomerase I. SpoIIIE is not absolutely required for vegetative growth, but it may facilitate clearance of DNA from the septum even in symmetric cell divisions.

\section{References}

1. Bacillus subtilis spoIIIE protein required for DNA segregation during asymmetric cell division.

2. Science, [http://www.sciencemag.org/] 